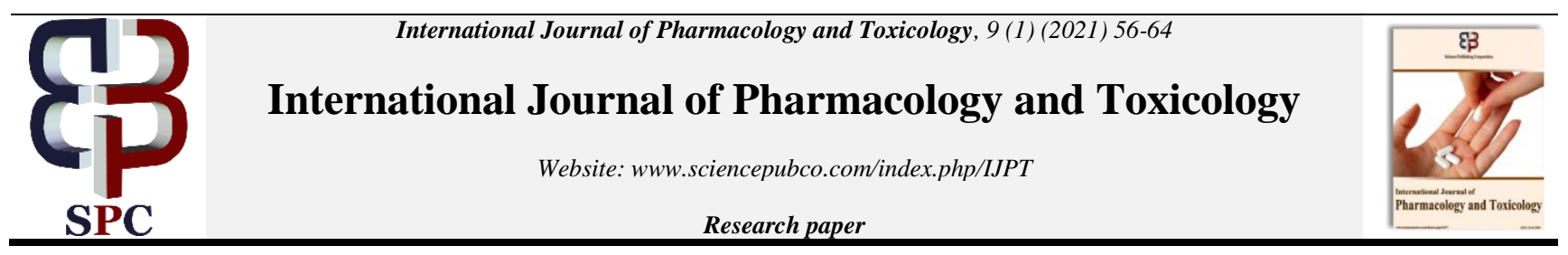

\title{
The immunibiochemical effect of synobiotic and phytobiotic in vaccinated and unvaccinated chicken
}

\author{
Marwa Kamel O. I. ${ }^{1 *}$, Ashraf A. A. El-Komy², Enas A. A. Farag ${ }^{2}$ \\ ${ }^{1}$ Animal Health Researches Institute, Benha Branch. \\ ${ }^{2}$ Department of pharmacology, faculty of Veterinary Medicine, Benha University, Egypt \\ *Corresponding author E-mail: marwawaelkoty@gmail.com
}

\begin{abstract}
The current study was conducted to evaluate the effects of dietary supplementation of synbiotics, phytobiotics and their mixture on some blood parameters with respct to kidney and liver functions and some histological criteria of broilers. A total of 200 broiler chicks were randomly chosen and divided into eight groups ( 25 bird in each). The first four groups were unvaccinated chicken and allotted to four dietary treatments, either fed a basal diet (group 1) or the same diet supplemented with $1 \mathrm{~g}$ synbiotic $/ \mathrm{kg}$ body weight ( group 2), $1 \mathrm{~g}$ phytobiotic $/ \mathrm{kg}$ body weight (group 3) and $1 \mathrm{~g}$ synbiotic plus $1 \mathrm{~g}$ phytobiotic/kg body weight (group 4).The same previous treatments were received by four vaccinated chicken groups 5, 6,7 and 8, respectively. Synobotic and phytobiotic tended to increase AST and ALT levels in vaccinated chicken during different periods. The mixture synbiotic and phytobiotic led to no significant increase in AST with unvaccinated and increase of ALT level in vaccinated groups. Also, previous feed additive increased total protein in both vaccinated and unvaccinated chickens. Supplementation mixture of both synbiotic and phytobiotic to diet increased total protein in unvaccinated and vaccinated chicken. Rations supplemented with synobiotic and phytobiotic increased albumin level in unvaccinated chicken and decreased with vaccinated chicken during different periods. Consequently, mixtures of synobiotic and phytobiotic appeared the same trend. On the other, using synobiotic and phytobiotic showed increase globulin level with unvaccinated chicken and decrease with vaccinated chicken, while the mixture of them gave higher level of globulin with unvaccinated or vaccinated chicken during different periods, except at 21 day, the globulin level had slight decrease with unvaccinated chicken. At the same time supplementation synobiotic and phytobiotic or their mixture with unvaccinated or vaccinated chicken revealed normal histological criteria. In conclusion, dietary supplementation of syonbiotic and phytobiotic improved the gut health by decreasing the caecal total coliform count with no adverse effect.

The aim of this experiment is to study the effect of dietary supplementation of synobiotic, phytobiotic and their mixture on kidney and liver functions and some histological criteria of broiler chicken.
\end{abstract}

Keywords: Synobiotic; Phytobiotic; Vaccinated; Unvaccinated; Chicken.

\section{Introduction}

Feed additives are used in animal feeding for a number of different reasons: effective as antibiotic to improve the health, performance of broiler chickens, growth promotion and increase immune response of chickens (Murarolli et al., 2014) .Probiotics have been defined as a live microbial feed supplement that can beneficially affect the intestinal microbial balance, resulting in improved body weight gain and reduce mortality in broiler chickens. Prebiotics are defined as no digestible, but fermentable, food ingredients as oligosaccharides that beneficially affect the host by selectively stimulating the growth and activity of one or limited number of species of probiotics bacteria in colon.

Synobiotic is defined as a combination of a probiotic and a prebiotic, aimed to increase the survival activity of probiotics in vivo and stimulating indigenous bifido bacteria and lactobacilli that supplementary digestive enzymes as amylase, cellulase, beta-glucanase ,hemicellulase improved nutrient digestibility, reduced small intestinal fermentation and increased cecal fermentation in chickens. The synobiotic had a comparable potential to improve broiler performance as Avilamycin (an antibiotic growth promoter) and play a role in the development of immune (Elsisi et al 2014).

Phytobiotic or phytogenic as feed additive is plant extracts derived from herbs or spices, which have biologically active compounds as well as aromatic and pharmacological properties. For many years, plant extracts and their essential oils (EO: a concentration of active components of plants) have been used as pharmaceuticals in alternative medicine and as a natural therapy. Both plant extracts and essential oils have been reported to have antimicrobial properties against a wide range of pathogenic microbial organisms in vitro and in vivo, lErdogan et $\mathrm{a}(2010)$

\section{Material and methods}

\subsection{Drugs}

Copyright $(\mathcal{O}$ Marwa Kamel O.I. et al. This is an open access article distributed under the Creative Commons Attribution License, which permits unrestricted use, distribution, and reproduction in any medium, provided the original work is properly cited. 


\subsubsection{Synobiotic}

a) Lactulose (lactulose 67\%)

This medication is a laxative used to treat constipation. It may help to increase the number of bowel movements per day and the number of days you have a bowel movement. Lactulose is a colonic acidifier that works by increasing stool water content and softening the stool.

b) lacteol fort (Lactobacillus LB) 6 Sachets

Composition: Each Sachet contains: Lactobacillus LB, Corresponding to lactobacillus delbruekii and lactobacillus fermentum. Treatment of acute and chronic diarrhea.

\subsubsection{Phytobiotic}

a) Ropadiar $20 \%$

Composition: carvacrol (oregano oil), thymol (oregano oil ), propylene glycol, polysorbate 80 E 433, alpha tocopherol ( Vit.E ). It was used as 1-2 ml per 10 litter water for 3 days. The product was used to improve productive efficiency for broiler chicken.

\subsection{Vaccine are used for increase immune responses against the most economically}

important chicken diseases (new castle vaccine)

\subsection{Instrument}

1) neubour's haemocytometer (for RBCs and WBCs count).

2) Centrifuge (MLWT 52-1 Germany) was used for separating serum.

3) Wintrobe haematocrit tubes for packed cell volume determination.

4) Deep freeze (-20 co) (Sital co., A.R.E.) was used for keeping serum samples.

5) Microtome (American Optical Company, U.S.A) was used for sectioning the tissues for histopathological studies.

6) Ordinary microscope (Car I- Zeiss 0.65 ) was used for histopathological examinations

7) Other equipment: beakers, bottles, cotton, flasks, forcipes, gauze, graduated cylinders, , scissors, syringes, and s were used.

\subsection{Chicks and experimental design}

200 chicks (one day old) were randomly chosen and divided into 8 groups, each group contains:

Group (1): 25 chicks were served as normal non treated group considered as control group. Group (2): 25 chicks of 14 day ages non vaccinated with ND were administrated $1 \mathrm{ml}$ synobiotic $/ \mathrm{kg}$ body weigh orally for 3 days. Group (3): 25 chicks of 14 day ages non vaccinated with ND were administrated $1 \mathrm{ml}$ phytobiotic $/ \mathrm{kg}$ body weigh orally for 3 days. Group (4):25 chicks of 14 day ages non vaccinated with ND were administrated $1 \mathrm{ml}$ mix of synobiotic and phytobiotic $/ \mathrm{Kg}$ body weight for 3 days Group (5) : 25 chicks were served as normal vaccinated group considered as control

group. Group(6) : 25 chicks of 14 day ages vaccinated with ND were administered $1 \mathrm{ml}$ synobiotic / $\mathrm{kg}$ body weight orally for 3 days . Group (7) : 25 chicks of 14 day ages vaccinated with ND were administrated $1 \mathrm{ml}$ phytobiotic / $\mathrm{kg}$ body weight orally for 3 days and Group( 8$)$ : 25 chicks of 14 day ages vaccinated with ND were administrated $1 \mathrm{ml}$ mix of synobiotic and phytobiotic /Kg body weight for 3 days .

\subsection{Sampling}

Blood samples were taken at the end of 7th day, 14th day and 21th post- treatment in all groups. Five birds of each group were sacrificed for collection of blood samples. Two blood samples were taken from each group for hematological and biochemical studies. The first blood sample was collected without anticoagulant for separation of clear serum for biochemical analysis. These serum samples were used for biochemical analysis to determine serum transaminases activities (AST and ALT), ALP, total protein, albumin, uric acid and creatinine The second sample of blood was collected in test tube mixed with heparin as anticoagulant. The sample was shacked several times to ensure mixing of blood with anticoagulant. These blood sample were used for hematological studies to determine erythrocytic count, total leucocytic count, hemoglobin concentration and packed cell volume. The treated chicks were sacrificed at 7 th, 10 th days and 15 th days post treatment. Specimens were collected from liver and intestine from each sacrificed tested chicks and fixed directly in formalin $10 \%$.

\subsection{Serum biochemical analysis}

Aspartate aminotransferase, serum alanine aminotransferase, total protein ,albumin, creatinine were determined. Determination (AST), (ALT) according to (Reitman and Frankel (1951). Determination of serum total protein and albumin level according to Doumas (1975). Determination of serum uric acid according to White et al., (1970). Determination of serum creatinine according to Folin (1934).

\subsection{Hematological studies}

Hemoglobin concentration, erythrocyte count and white blood cells were counted by using automatic blood cell counter (model HA-VET CLINDIAG).

\subsection{Histopathology study}

The treated chicks were sacrificed at 7,14 and 21 days post treatment. Specimens were collected from liver, thymus, bursa and kidney from each sacrificed tested chicks and fixed directly in formalin $10 \%$.

The fixed tissues in formal were processed by dehydration in different concentrations of ethanol, cleared with xylol and embedded in paraffin, serial sections of 4-5 microns, which were stained with Hematoxylin and Eosin (Banchroft,1996) for histopathology examinations. 


\section{Statistical analysis}

Statistical analysis was conducted with the Statistical Package for Social Science (SPSS 16 Inc. Released, 2009) to determine if variables differed among groups. Comparison among means was conducted by one-way ANOVA and subsequent Ducann's multiple range test (1955), Probability values of less than $5 \%(\mathrm{p} \leq 0.05)$ were considered significant

\section{Results}

Effect on liver function: -

1) The effect on serum AST:

Table (1) showed the effect of administration synobiotic and phytobiotic and mixture of them in unvaccinated and vaccinated chicken. Demonstrated Therapeutic dose of synobiotic and phytobiotic $(1 \mathrm{ml} / \mathrm{kg}$ body weight $)$ orally for 3 days showed no significant increase in AST level at 7,14 and 21 day compared to control group and severe increase on AST level in vaccinated chicken at 7,14 and 21day compared to control group. Mixture of synobiotic and phytobiotic showed no significant increase on AST level in unvaccinated chicken but showed high increase for AST level in vaccinated chicken compared to control group.

2) The effect on serum ALT:

Table (1) showed the effect of administration synobiotic and phyobiotic and mixture of them in unvaccinated, vaccinated chicken. Demonstrated Therapeutic dose of synobiotic and phyobiotic ( $1 \mathrm{ml} / \mathrm{kg}$ body weight) orally for 3 days showed decrease in ALT level at 7,14 and 21day compared to control group in unvaccinated chicken and high increase on ALT level in vaccinated chicken at 7,14 and 21 day compared to control group, while mixture of synobiotic and phytobiotic showed decrease in ALT level in unvaccinated chicken but showed high increase in ALT level with vaccinated chicken compared to control group.

3) Effect on serum Total protein:

Table (2) showed the effect of administration synobiotic and phytobiotic and mixture of them in unvaccinated, vaccinated chicken. Therapeutic dose of synobiotic and phytobiotic ( $1 \mathrm{ml} / \mathrm{kg}$ body weight) orally for 3 days on total protein level showed increase in total protien level at 7,14 and 21day compared to control group with unvaccinated chicken and severe increase in total protein level for vaccinated chicken at 7,14 and 21day compared to control group .Mixture of synobiotic and phytobiotic showed sever increase for total protein level in non vaccinated and vaccinated chicken compared to control group.

4) Effect on serum albumin:

Table (2) showed the effect of administration synobiotic and phytobiotic and mixture of them in non vaccinated and vaccinated chicken. Administration synobiotic ( $1 \mathrm{ml} / \mathrm{kg}$ body weight) with non vaccinate chicken showed increase in albumin level at 7,14 and 21 day compared to control group but showed decrease in total albumin level with vaccinated chicken at 7,14 and 21day. Administration of phytobiotic $(1 \mathrm{ml} / \mathrm{kg}$ body weight) orally for 3 days in non vaccinated chicken showed increase in albumin level at 7,14 and 21 day compared to control group and severe decrease on albumin level in vaccinated chicken at 7,14 and 21 day). ). Mixture of synobiotic and phytobiotic showed significant increase in albumin level with unvaccinated chicken but showed no significant increase in albumin level at 7 day and decrease albumin level at 14 and 21 day compared to control group in vaccinated chicken .

5) Effect on globulin:

Table (2) showed the effect of administration synobiotic and phytobiotic and mixture of them in non vaccinated and vaccinated chicken. Demonstrsted therapeutic dose of synobiotic and phyobiotic ( $1 \mathrm{ml} / \mathrm{kg}$ body weight) orally for 3 days showed increase in globulin level at 7,14 and 21 day compared to control group. The same previous trend was shown with vaccinated chicken at the same periods. compared to control group. Mixture of synobiotic and phytobiotic showed sever increase in globulin level with unvaccinated chicken at 7 day and 14 day and slight decrease at 21 day, but showed high and severe increase globulin level in vaccinated chicken at 7,14 and 21 day compared to control group.

Table 1: Effect of Feed Additives on ALT and AST (Mean \pm SE)

\begin{tabular}{|c|c|c|c|c|c|c|c|}
\hline \multirow{2}{*}{ Treatments } & & \multicolumn{3}{|l|}{ ALT (U/L) } & \multicolumn{3}{|l|}{ AST (U/L) } \\
\hline & & 7 days & 14 days & 21 days & 7 days & 14 days & 21 days \\
\hline \multirow{4}{*}{$\begin{array}{l}\text { Non vac- } \\
\text { cinated }\end{array}$} & Control (-ve) & $25.72 \pm 0.61^{\text {bcd }}$ & $27.07 \pm 0.34^{\mathrm{bc}}$ & $28.21 \pm 0.92^{\mathrm{bc}}$ & $50.85 \pm 0.38^{c}$ & $50.96 \pm 2.03^{\mathrm{cd}}$ & $53.05 \pm 0.36^{\mathrm{c}}$ \\
\hline & Synobiotic $(1 \mathrm{ml} / \mathrm{kg})$ & $24.96 \pm 0.24^{\mathrm{cd}}$ & $25.49 \pm 0.26^{\mathrm{cd}}$ & $25.66 \pm 0.53^{\mathrm{cd}}$ & $51.49 \pm 1.56^{\mathrm{c}}$ & $53.65 \pm 0.69^{\mathrm{cd}}$ & $50.11 \pm 0.64^{c}$ \\
\hline & Phytobiotic $(1 \mathrm{ml} / \mathrm{kg})$ & $25.16 \pm 0.47^{\mathrm{cd}}$ & $25.65 \pm 0.27^{\mathrm{cd}}$ & $24.66 \pm 0.70^{\mathrm{cd}}$ & $52.82 \pm 0.97^{\mathrm{c}}$ & $50.63 \pm 0.85^{\mathrm{cd}}$ & $52.13 \pm 0.80^{c}$ \\
\hline & $\begin{array}{l}\text { Synobiotic + hytobiotic (1 ml } \\
/ \mathrm{Kg})\end{array}$ & $22.98 \pm 0.22^{\mathrm{d}}$ & $21.46 \pm 1.71^{\mathrm{d}}$ & $21.65 \pm 1.37^{\mathrm{d}}$ & $49.87 \pm 1.09^{c}$ & $49.57 \pm 0.54^{\mathrm{d}}$ & $48.03 \pm 1.93^{\mathrm{c}}$ \\
\hline \multirow{4}{*}{ Vaccinated } & Control (-ve) & $25.93 \pm 1.36^{\mathrm{abcd}}$ & $27.93 \pm 0.85^{\mathrm{bc}}$ & $27.47 \pm 1.24^{\mathrm{c}}$ & $53.58 \pm 2.97^{\mathrm{c}}$ & $58.00 \pm 2.26^{\mathrm{bc}}$ & $54.53 \pm 3.03^{\mathrm{bc}}$ \\
\hline & Synobiotic $(1 \mathrm{ml} / \mathrm{kg})$ & $29.40 \pm 2.14^{\mathrm{a}}$ & $34.33 \pm 0.62^{\mathrm{a}}$ & $33.93 \pm 2.47^{\mathrm{a}}$ & $67.57 \pm 3.54^{b}$ & $64.10 \pm 2.18^{\mathrm{ab}}$ & $78.63 \pm 3.26^{\mathrm{a}}$ \\
\hline & Phytobiotic $(1 \mathrm{ml} / \mathrm{kg})$ & $29.20 \pm 0.97^{\mathrm{ab}}$ & $32.43 \pm 2.96^{\mathrm{ab}}$ & $32.53 \pm 1.56^{\mathrm{ab}}$ & $78.73 \pm 3.55^{\mathrm{a}}$ & $68.23 \pm 6.36^{\mathrm{a}}$ & $71.47 \pm 4.97^{\mathrm{a}}$ \\
\hline & $\begin{array}{l}\text { Synobiotic + hytobiotic }(1 \mathrm{ml} \\
\text { /Kg) }\end{array}$ & $27.69 \pm 1.68^{\mathrm{abc}}$ & $29.83 \pm 3.36^{\mathrm{ab}}$ & $32.87 \pm 1.79^{\mathrm{a}}$ & $71.32 \pm 1.31^{\mathrm{b}}$ & $67.37 \pm 1.05^{\mathrm{a}}$ & $60.83 \pm 1.60^{\mathrm{b}}$ \\
\hline
\end{tabular}

Table 2: Effect of Feed Additives on Total Protein, Albumin and Globulin (Mean \pm SE)

\begin{tabular}{|c|c|c|c|c|c|c|c|c|c|c|c|c|c|}
\hline \multirow{2}{*}{\multicolumn{2}{|c|}{ Treatments }} & \multicolumn{2}{|c|}{ Total protein $(\mathrm{g} / \mathrm{dl})$} & \multicolumn{4}{|c|}{ Albumin $(\mathrm{g} / \mathrm{dl})$} & \multicolumn{3}{|c|}{ Globulin (g/dl) } & \multicolumn{3}{|c|}{$\mathrm{A} / \mathrm{G}$ ratio } \\
\hline & & 7 Days & 14 days & 21 days & 7 days & $\begin{array}{l}14 \\
\text { days }\end{array}$ & 21 days & 7 days & 14 days & 21 days & 7 days & 14 days & 21 days \\
\hline \multirow{3}{*}{ 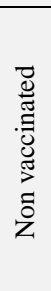 } & $\begin{array}{l}\text { Control } \\
\text { (-ve) }\end{array}$ & $\begin{array}{l}4.28 \\
\pm 0.29^{c}\end{array}$ & $\begin{array}{l}4.06 \\
\pm 0.24^{\mathrm{d}}\end{array}$ & $\begin{array}{l}4.52 \\
\pm 0.11^{\mathrm{bc}}\end{array}$ & $\begin{array}{l}2.68 \\
\pm 0.07^{\mathrm{ab}}\end{array}$ & $\begin{array}{l}2.52 \\
\pm 0.14^{\mathrm{b}}\end{array}$ & $\begin{array}{l}2.18 \\
\pm 0.01^{\mathrm{d}}\end{array}$ & $\begin{array}{l}1.60 \\
\pm 0.35^{\text {bc }}\end{array}$ & $\begin{array}{l}1.55 \\
\pm 0.38^{\mathrm{bc}}\end{array}$ & $\begin{array}{l}2.34 \\
\pm 0.09^{\mathrm{b}}\end{array}$ & $\begin{array}{l}1.77 \\
\pm 0.43^{\mathrm{ab}}\end{array}$ & $\begin{array}{l}1.75 \\
\pm 0.51^{\mathrm{b}}\end{array}$ & $\begin{array}{l}0.93 \\
\pm 0.03^{\text {cd }}\end{array}$ \\
\hline & $\begin{array}{l}\text { Synobi- } \\
\text { otic (1 } \\
\mathrm{ml} / \mathrm{kg})\end{array}$ & $\begin{array}{l}4.85 \\
\pm 0.17^{\mathrm{b}}\end{array}$ & $\begin{array}{l}5.39 \\
\pm 0.31^{\text {abc }}\end{array}$ & $\begin{array}{l}5.09 \\
\pm 0.14^{\mathrm{ab}}\end{array}$ & $\begin{array}{l}2.88 \\
\pm 0.12^{\mathrm{ab}}\end{array}$ & $\begin{array}{l}3.09 \\
\pm 0.13^{\mathrm{a}}\end{array}$ & $\begin{array}{l}2.68 \\
\pm 0.09^{\mathrm{abc}}\end{array}$ & $\begin{array}{l}1.96 \\
\pm 0.17^{\mathrm{abc}}\end{array}$ & $\begin{array}{l}2.30 \\
\pm 0.21^{\mathrm{ab}}\end{array}$ & $\begin{array}{l}2.42 \\
\pm 0.09^{\mathrm{ab}}\end{array}$ & $\begin{array}{l}1.49 \\
\pm 0.16^{\mathrm{abc}}\end{array}$ & $\begin{array}{l}1.36 \\
\pm 0.10^{\mathrm{bc}}\end{array}$ & $\begin{array}{l}1.11 \\
\pm 0.05^{\text {bcd }}\end{array}$ \\
\hline & $\begin{array}{l}\text { Phyto- } \\
\text { biotic } \\
(1 \\
\mathrm{ml} / \mathrm{kg})\end{array}$ & $\begin{array}{l}5.29 \\
\pm 0.21^{\mathrm{ab}}\end{array}$ & $\begin{array}{l}5.30 \\
\pm 0.23^{\mathrm{abc}}\end{array}$ & $\begin{array}{l}5.41 \\
\pm 0.28^{a}\end{array}$ & $\begin{array}{l}3.03 \\
\pm 0.12^{\text {ab }}\end{array}$ & $\begin{array}{l}2.91 \\
\pm 0.18^{\mathrm{ab}}\end{array}$ & $\begin{array}{l}2.91 \\
\pm 0.09^{\mathrm{a}}\end{array}$ & $\begin{array}{l}2.26 \\
\pm 0.32^{\mathrm{ab}}\end{array}$ & $\begin{array}{l}2.38 \\
\pm 0.37^{\mathrm{a}}\end{array}$ & $\begin{array}{l}2.50 \\
\pm 0.36^{\mathrm{ab}}\end{array}$ & $\begin{array}{l}1.42 \\
\pm 0.30^{\mathrm{abc}}\end{array}$ & $\begin{array}{l}1.29 \\
\pm 0.24^{\mathrm{bc}}\end{array}$ & $\begin{array}{l}1.23 \\
\pm 0.22^{\mathrm{bc}}\end{array}$ \\
\hline
\end{tabular}




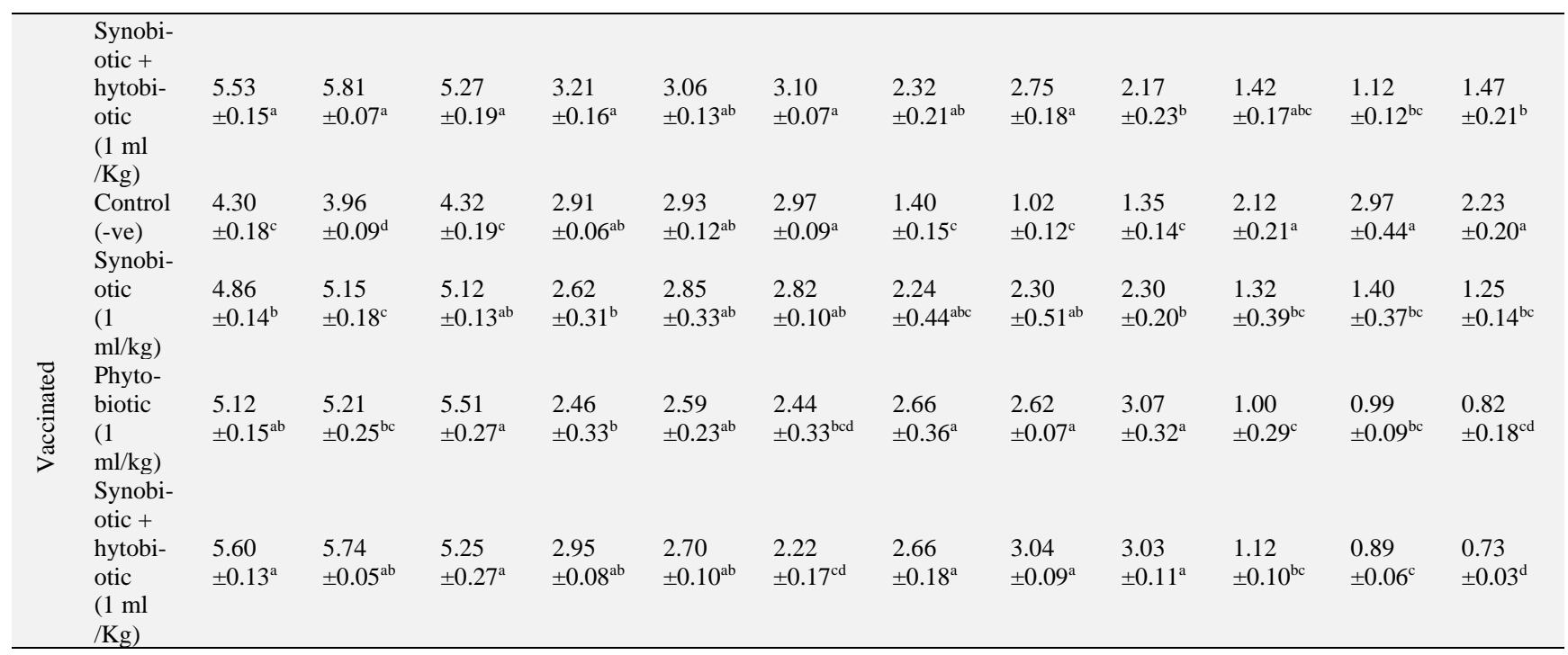

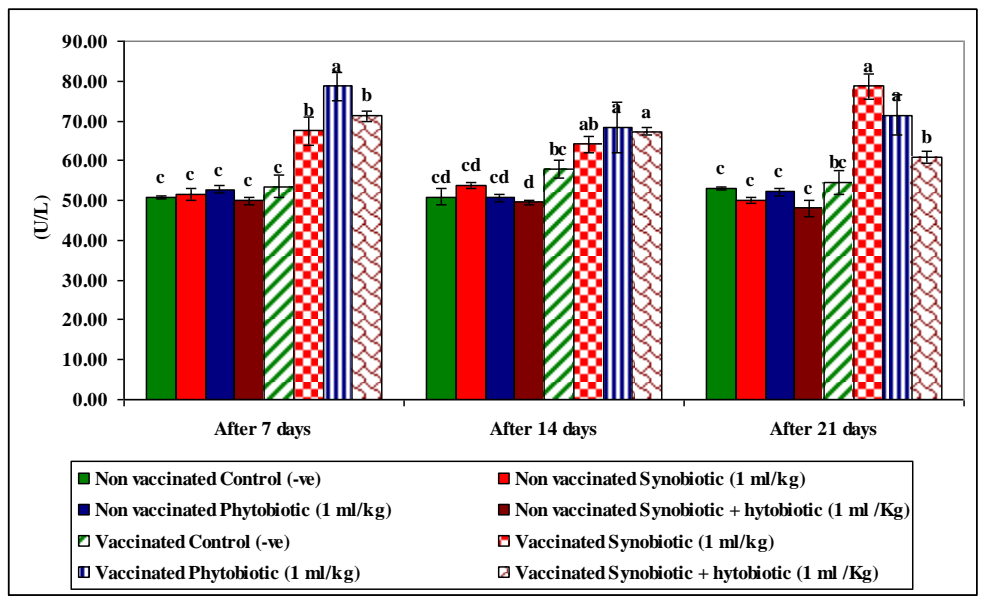

Fig. 1: AST.

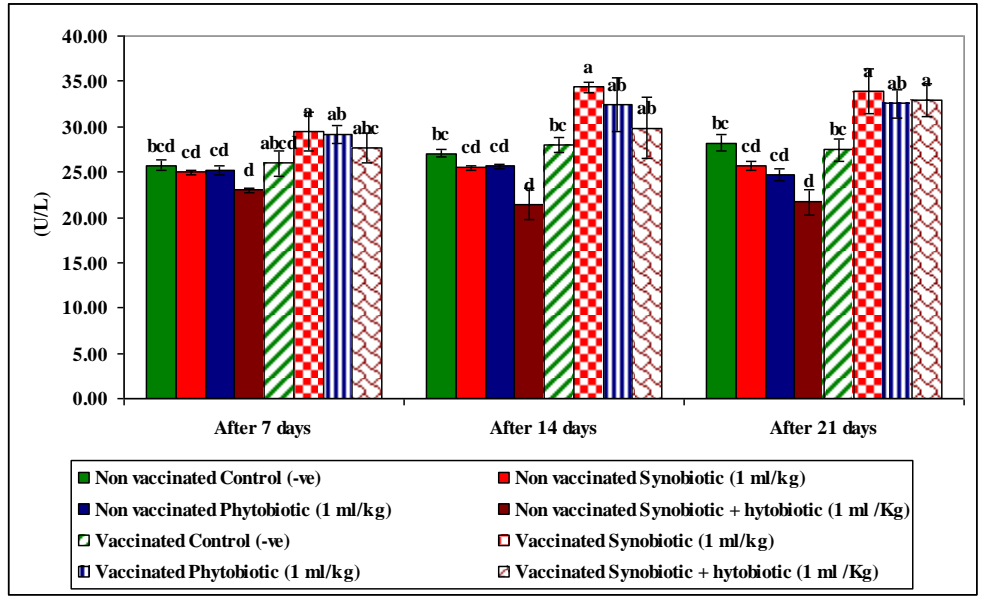

Fig. 2: AlT. 


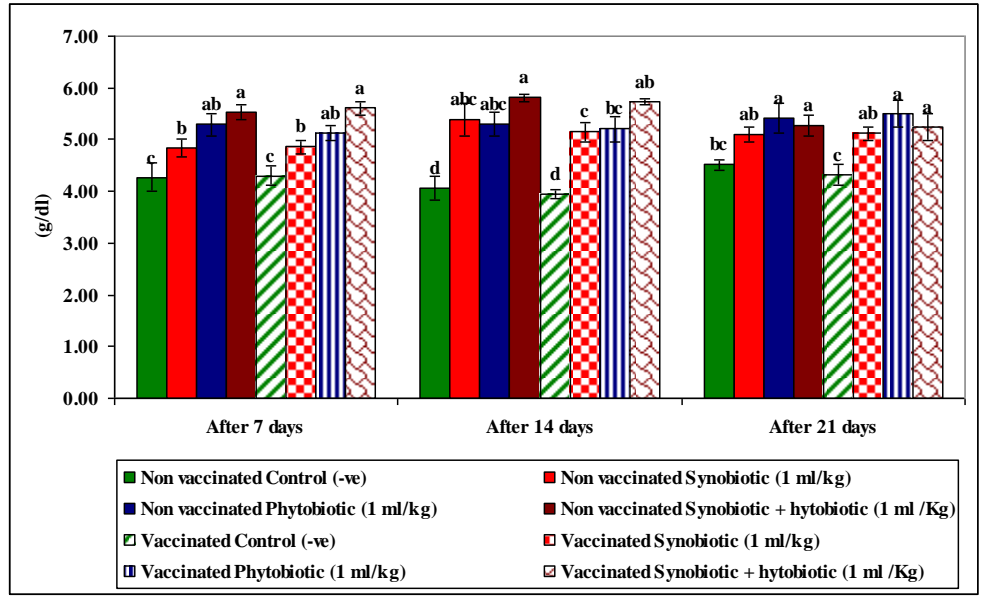

Fig. 3: Total Protein.

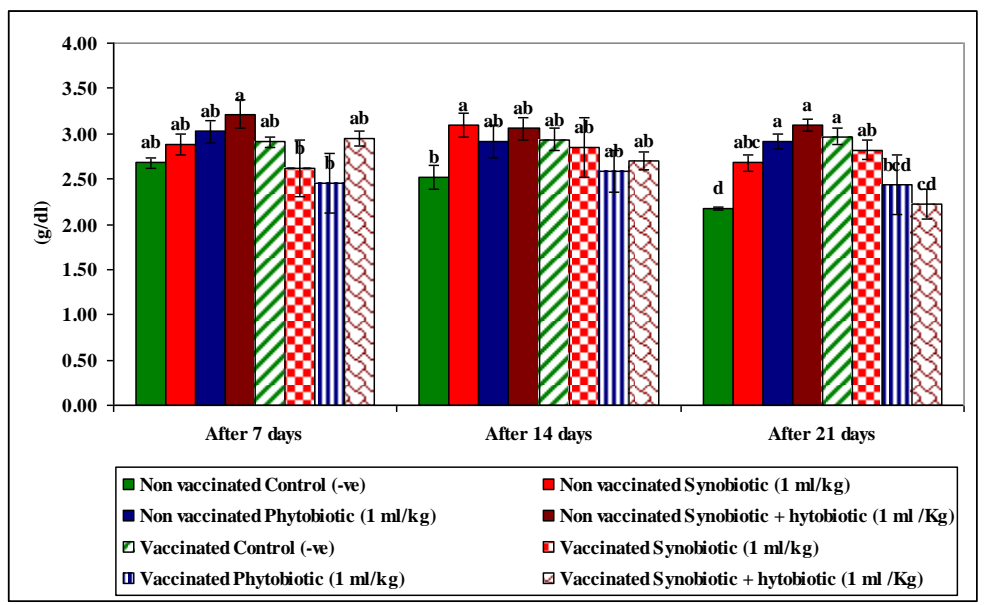

Fig. 4: Albumin.

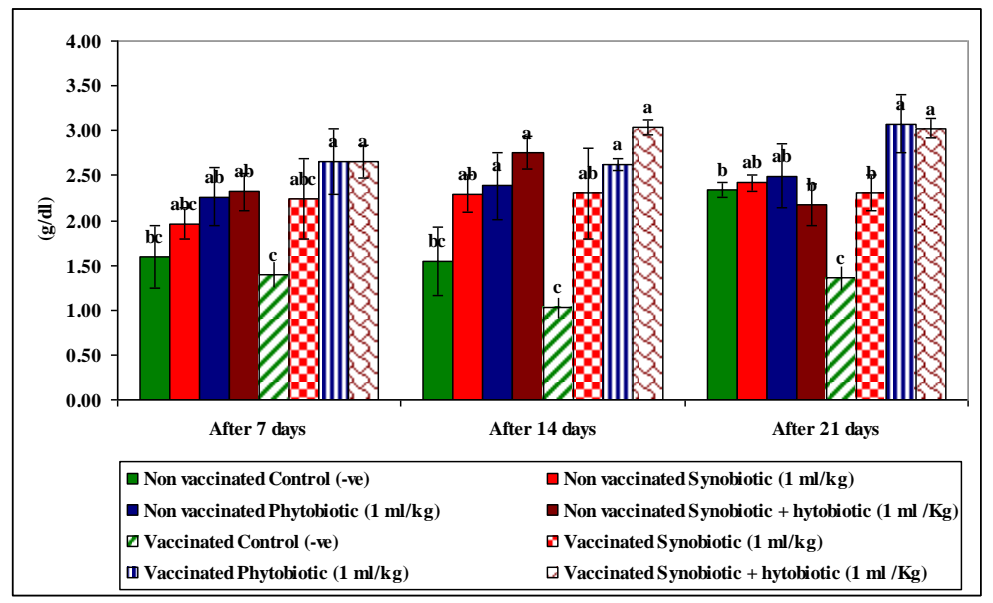

Fig. 5: Globulin.

Microscopic examination of different sections were taken form specimens of Liver. Hepatic cords of unvaccinated chicken group (control group) showed normal histological criteria (figure1). Hepatic cords revealed vacuolar degeneration and foci of inflammatory cells (figure 2). Hepatic parenchyma revealed inflammatory cells infiltrations both in diffuse and focal aggregation pattern (figure 3). Hepatic parenchyma with dilated sinusoids containing fibrinous exudate (figure 4). Hepatic parenchyma showed sinusoidal dilation, large area of hepatic parenchyma replaced by foci of inflammatory cell, other area was necrosed (figure 5). Liver showing dilated sinusoids associated with peri-vascular inflammatory cells infiltration (figure 6). Liver with necrobiotic changes of hepatocytes and loss of hepatic architecture associated with foci of inflammatory cells infiltration (figure 7). Hepatic parenchyma showing peri-vascular heterophilic infiltration associated with mild dilation of sinusoids (vaccinated chicken with phytobiotic) (figure 8) .Hepatic sinusoids filled with fibrinous exudate in association with thickened vasculature vaccinated chicken mix with synobiotic and phytobiotic (figure 9). 


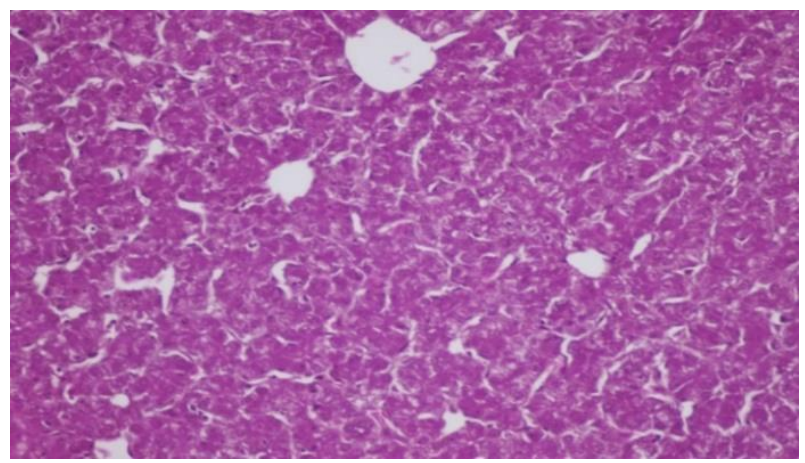

Fig. 1: Hepatic Cords Revealing Normal Histological Criteria.

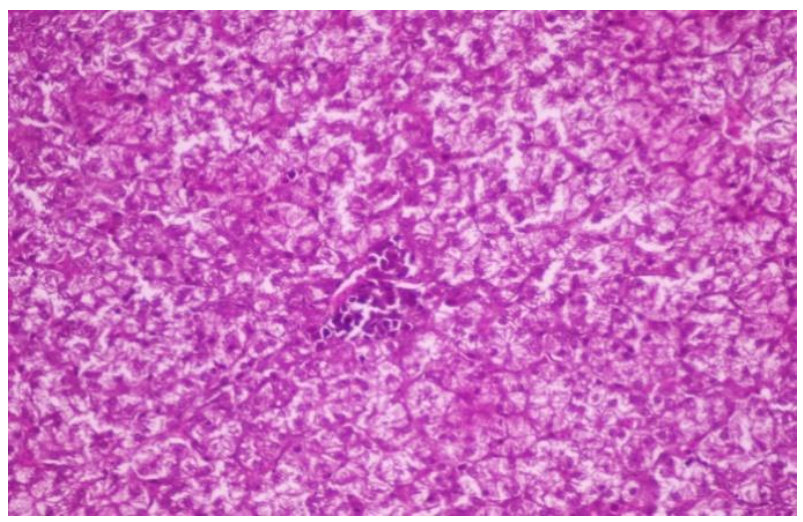

Fig. 2: Hepatic Cords Revealing Vacuolar Degeneration and Foci of Inflammatory Cells.

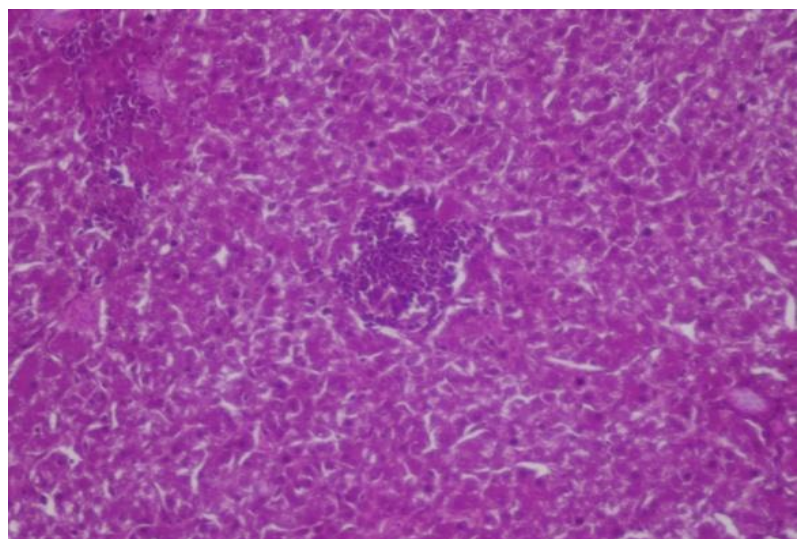

Fig. 3: Hepatic Parenchyma Revealing Inflammatory Cells Infiltrations Both in Diffuse and Focal Aggregation Patter(Non Vaccinated Chicken with Phytobiotic).

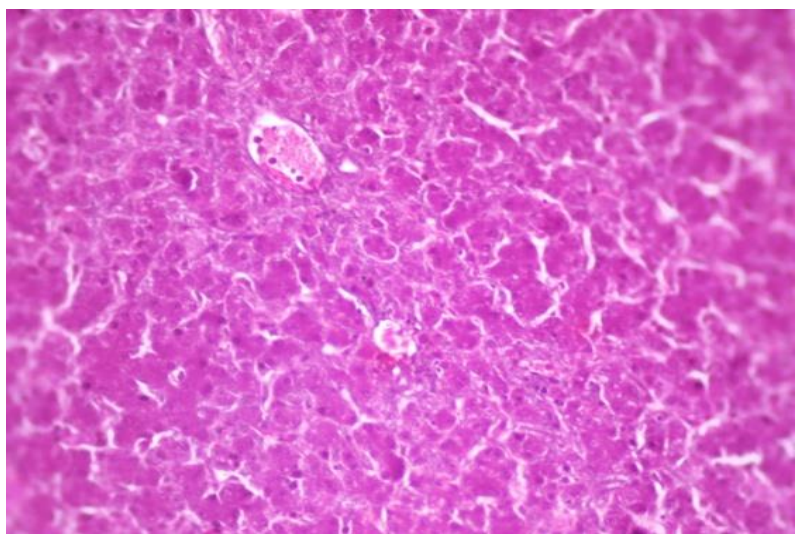

Fig. 4: Hepatic Sinusoids Filled with Fibrinous Exudate in Association with Intra-Vascular Thrombus Formation (No Vaccinated Mix with Symbiotic and Photobiotic). 


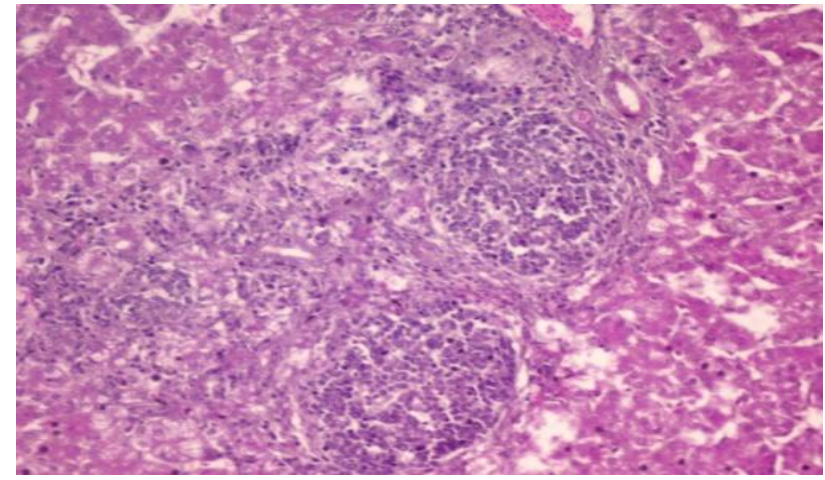

Fig. 5: Hepatic Parenchyma Showed Sinusoidal Dilation, Large Area of Hepatic Parenchyma Replaced by Foci of Inflammatory Cell, Other Area was Necrosed (No Vaccinated Chicken Mix with Synobiotic and Phytobiotic.

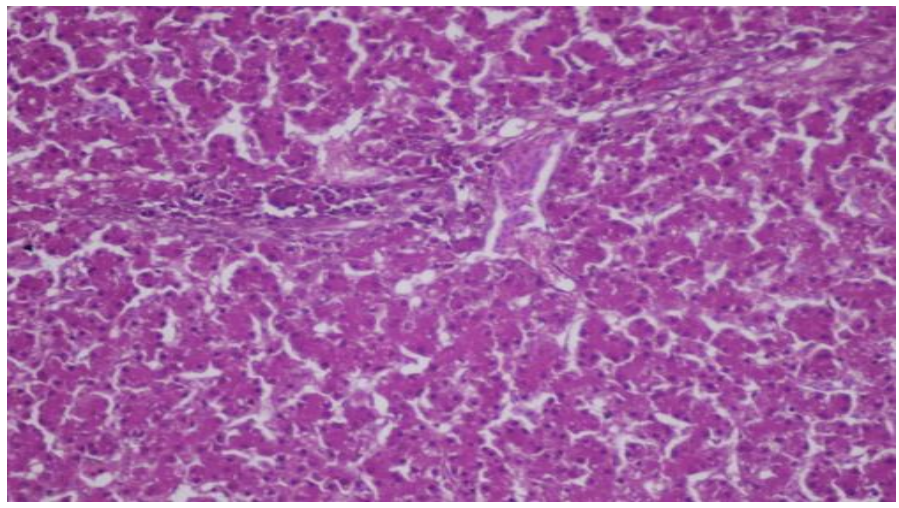

Fig. 6: Liver Showing Dilated Sinusoids Associated with Pre-Vascular Inflammatory Cells Infiltration. (Normal Vaccinated Chicken).

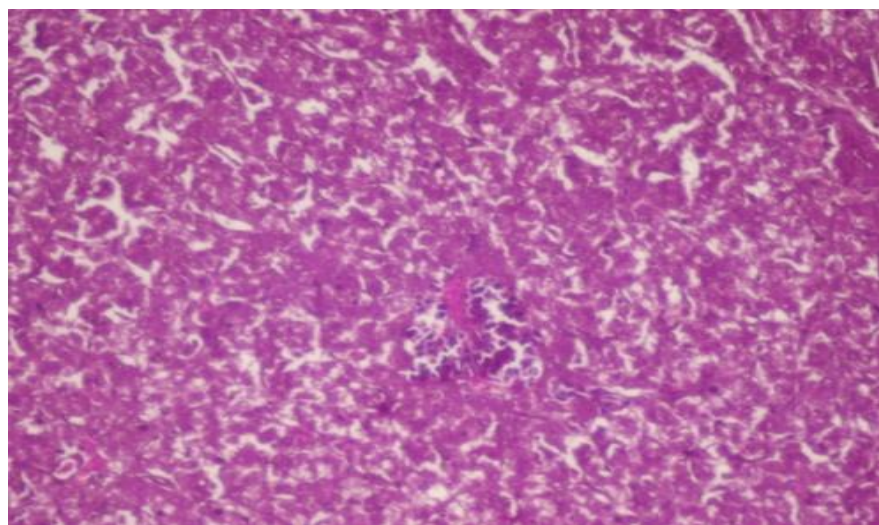

Fig. 7: Liver with Necrobiotic Changes of Hepatocytes and Loss of Hepatic Architecture Associated with Foci of Inflammatory Cells Infiltration (Vaccinated Chicken with Symbiotic).

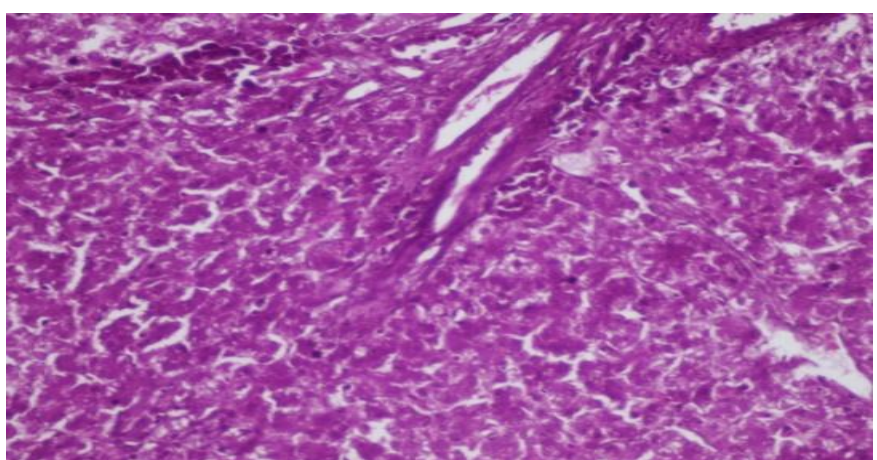

Fig. 8: Hepatic Parenchyma Showing Pre-Vascular Heterophilic Infiltration Associated with Mild Dilation of Sinusoids (Vaccinated Chicken with Photobiotic). 


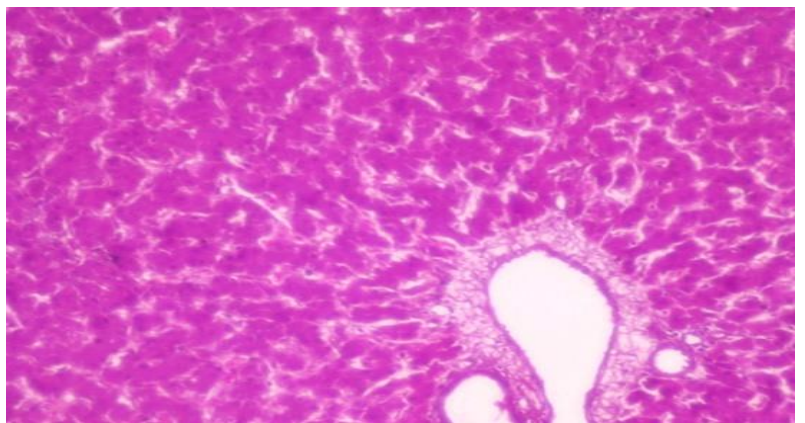

Fig. 9: Hepatic Sinusoids Filled with Fibrinous Exudate in Association with Thickened Vasculature Vaccinated Chicken Mix with Synobiotic and Phytobiotic.

\section{Discussion}

Synbiotics refer to food ingredients or dietary supplements combining probiotics and prebiotics in a form of synergism. The synbiotic concept was first introduced as mixtures of probiotics and prebiotics that beneficially affect the host by improving the survival and implantation of live microbial dietary supplements in the gastrointestinal tract, by selectively stimulating the growth and/or by activating the metabolism of one or a limited number of health-promoting bacteria, thus improving host Phytobiotics can be defined as plant derived products added to feed in order to improve performance. They originate from leaves, roots, tubers or fruits of herbs, spices and other plants. They may be available in solid, dried, and ground forms, or as extracts (essential oils).

Liver plays a central role in metabolism of drug and xenobiotics, protein synthesis and in maintaining biologic equilibrium, of organisms. Due to these important roles, liver enzymes are used as markers in the assessment of drug safety or toxicity (Satyapal et al., 2008). The transaminases are involved in intermediary metabolism and are thus present in high concentration in the liver; they are rapidly released into the serum in cases of acute destruction of tissues as in myocardial infarction or hepatocellular necrosis (Tietz 2000).

Kidney is an important organ having not only excretory function but also other functions such as production of the substances that activates a living body, enzymatic reaction, immunization. The kidney is often involved in the development, maintenance and counter regulation of complex electrolyte disturbances (Heidland et al., 1985).

The effect of therapeutic dose of synobiotic and phytobiotic ( $1 \mathrm{ml} / \mathrm{kg}$. body weight), orally for 3 successive days on AST and ALT level in chickens showed no significant increase in AST level and decrease in ALT level with unvaccinated chicken compared to control group. Results were agreement with Akbarian et al., (2012). In vaccinated chicken severe increase in AST and ALT level at7,14 and 21 day. These result agree with Sawsan et al.(2019) who reported that the dietary inclusion of Phytobiotic in broilers resulted in significant improvement of their growth performance and liver functions. Sobayo et al.(2013) studied hematological, serum and carcass characteristics of broiler chicken fed 'graded levels of garcinia kola (bitter kola) used as phytobiotic resulted in increase in serum aspartate aminotransferase (SAST). Therapeutic dose of synobiotic and phytobiotic $(1 \mathrm{ml} / \mathrm{kg}$. body weight), orally for 3 successive days on total protein and albumin showed a significant increase on total protein and albumin at 7, 14 and 21 day. These results coordinates with Amad et al. (2011) who reported an increase in protein level by increasing phytogenic feed additive in feed as described by Ashayerizadeh et al., (2011). Abdelrafea et al., (2013) studied the effects of Astragalus membranaceus root powder (AMRP) additions on growth performance, physiological and serum indices in broiler chicken. They showed significant elevation in serum total protein, albumin and also agree with Vivian OleforuhOkoleh et al., (2015) who reported significant increase in the total protein, albumin by using aqueous extract of ginger and garlic in unvaccinated chicken. The albumin level increased at the end of the experiment as shown by Sobayo et al.(2013) who studied serum and carcass characteristics of broiler chicken fed 'graded levels of garcinia kola (bitter kola) which used as phytobiotic.

Our results showed that administration of synobiotic and phytobiotic orally for 3 successive days on Hb, RBCs, PCV percentages of chickens showed significant increase at 7day ,14day and 21 day. These results were agremeent with Jagmohan Singh et al., (2013) who evaluated the effects of Aloe vera on dressing percentage ,hematological and biochemical parameters of broiler chickens. They showed significantly higher value of hemoglobin concentration, PCV percentage level as compared to control groups. The results were also agremeent with those reported by Sobayo et al., (2013) who studied hematological, serum and carcass characteristics of broiler chicken fed 'graded levels of garcinia kola. They found the highest hemoglobin, packed cell volume (PCV) and red blood cells (RBC) values. The results were also agreement with those the finding of Alaeldein and Mohamed (2015) who studied the effect of dietary inclusion of probiotic and prebiotic or their combination on growth performance of broiler chickens.

\section{Conclusion}

The present study by adminsration of synobiotic and phytobiotic lead to significant improvement of growth performance, liver and kidney functions of brolier chicken.

\section{Acknowledgment}

Author would like to express her deepest gratitude and sincere thanks to Prof. Dr. Ashraf A.A. EL-Komy, Professor and head of Pharmacology Department, Faculty of Veterinary Medicine, Benha University, for his guidancy and helps and Dr. Enas A. H. Farag Deputy Animal Health Research Institute, Benha Branch, for her continual direction and helps.

\section{References}

[1] Amad, A.A.; Männer, K.; Wendler, K.R.; Neumann, K. and Zentek, J. (2011). Effects of a phytogenic feed additive on growth performance and ileal nutrient digestibility in broiler chickens. Poultry Science, 90: 2811-281. https://doi.org/10.3382/ps.2011-01515.

[2] Abdelrafea A. E.; Mohammed A. A.; Abdelrahman A.S. and Arafa, M.M. (2013): Influence of Different Levels of Astragalus Root Powder in Broiler Chick Diets on the Physiological and Biochemical Changes. Journal of Applied Sciences Research, 9(3): 2104-2118, 2013 ISSN 1819-544X. 
[3] Akbarian, A.; Golian, A.; Kermanshahi, H.; Gilani, A. and Moradi, S. (2012): Influence of turmeric rhizome and black pepper on blood constituents and performance of broiler chickens. African Journal of Biotechnology, 11(34): 8606-8611. https://doi.org/10.5897/AJB11.3318.

[4] Alaeldein M. A.; Mohamed A.M. (2015): Effects of the Dietary Inclusion of a Probiotic, a Prebiotic or their Combinations on the Growth Performance of Broiler Chickens. Brazilian Journal of Poultry Science. . vol.17 .099-104.

[5] Ashayerizadeh A.; Dabiri N.; Mirzadeh K. H. M. and Ghorbani M. R. (2011): Paper Effect of dietary supplementation of probiotic and prebiotic on growth indices and serum biochemical parameters of broiler chickens. Journal of Cell and Animal Biology Vol. 5(8), pp. 152-156

[6] Bancroft, J.D.and Gamble, M. (2008):"Theory and Practice of Histological Techniques."' 6th ED., Churchill Livingstone, Elsevier, China. 2008.

[7] Doumas, B. T. (1975): Colorimetric determination of total proteins.Clin. chem.21,1159.1166. https://doi.org/10.1093/clinchem/21.8.1159.

[8] Duncan, D.B. (1955): Multiple range and multiple F tests. Biometrics 11: 1-42. https://doi.org/10.2307/3001478.

[9] Erdogan, Z.; Erdogan, S.; Aslantas,O. and Celik,S. (2010) : Effects of dietary supplementation of synbiotics and phytobiotics on performance, caecal coliform population and some oxidant/antioxidant parameters of broilers .Journal of Animal Physiology and Animal Nutrition https://doi.org/10.1111/j.1439-0396.2009.00973.x.

[10] Folin, O. Z.(1934): Colorimetric determination of creatinine Phys.Chem.268:228. https://doi.org/10.1515/bchm2.1934.228.3-6.268.

[11] Heidland A.; Horl W.H.; Schaefer R.M.; Teschner M.; Weipert J.and Heidbreder E. (1985): Role of alcohol in clinical nephrology.. Klin Wochenschr ;63:948. https://doi.org/10.1007/BF01738150.

[12] Jagmohan Singh.; K. M. Koley.; Khushboo Chandrakar. and Nileshkumar S. Pagrut. (2013): Effects of Aloe vera on dressing percentage and haematobiochemidal parameters of broiler chickens. Veterinary World, EISSN: 2231-0916. https://doi.org/10.14202/vetworld.2013.803-806.

[13] Murarolli V.I; Burbarelli M.; Polycarpo G.I; Ribeiro P.; Moro M.AND Albuquerque R. (2014): Prebiotic, probiotic and symbiotic as alternative to ntibiotics on the Performance and Immune Response of Broiler Chickens. Brazilian Journal of Poultry Science. . vol.16 no.3. https://doi.org/10.1590/1516-635x1603279-284.

[14] Reitmans, S. and Frankel, S. (1957): Reitman-Frankel colourimetric method of Got/ As T and GPT/ALT Tromsaminales. Am. J. Clin. Path. 28: 5663. https://doi.org/10.1093/ajcp/28.1.56

[15] Sawsan M. E.; Abdalim F. A.; Mohamed K. M.; Mohamed S. H. E and (2019) Science. Volume 10 (3): 134-140, 2016.

[16] Sobayo R.A., Adeyemi O.A., Oso A.O., Fafiolu A.O., Daramola J.O., Sodipe G., I Ogunade IB, Odetolao O.M.(2013): Haematological, serum and carcass characteristics of broiler chicken fed 'graded levels of Garcinia kola (Bitter kola) used as phytobiotic. Nigerian Journal of Animal Production. Vol 40, No 1. https://doi.org/10.51791/njap.v40i1.623.

[17] Satyapal S.U.; Kadam V.J.and Ghosh R. (2008): Hepatoprotective activity of Livobond, a polyherbal formulation against CCl4 induced hepatotoxicity in rats. Int J Pharm; 4:472-6. https://doi.org/10.3923/ijp.2008.472.476.

[18] Sawsan M. E.; Abdalim F. A.; Mohamed K. M.; Mohamed S. H. E and Science. Volume 10 (3): 134-140, 2016.

[19] Sanja J. P.; Ljiljana M. K., Nikola M. P., Jovanka D. L., Olivera M. Đ.; Bojana M. K.; Ivana S. Č.and Marina V. V. (2015): Effect of synbiotic on growth and antioxidant status of blood in broiler chicken Journal of the Institute of Food Technology in Novi Sad. Volume 42, Issue 2.163-169

[20] Tietz N.W. (2000): Fundamentals of clinical chemistry. 6 thed Philadephia, PA: Saunders. p. 744-5, 788-9.

[21] White, B. A.; Erickson, M. M.; and Stevens, S.G. (1970): Colorimetric determination of uric acid. Chemistry for medical technologists 3rd ed C. V. Mosby Company, saint Louis, U. 